\title{
Black Sea as Literary and Cultural Space: State of the Art and Prospects
}

\author{
By Yordan Lyutskanov ${ }^{*}$
}

It is argued that the notion of 'literary space', as developed from diverse perspectives by scholars within the disciplinary contexts of cultural geography and literary studies, is a convenient tool to evoke interdisciplinary research that has its focal area about literary studies; and hence potentially contributing to overcome a state of the art which perpetuates the position of studies on the Black Sea literatures and cultures at the margin of humanities (or: on the verge of not being constituted as a subject in humanities). Attempting a critical overview, I discern two main shortcomings of studies on the Black Sea region/area: (i) a tendency to 'naturalise' and dehumanise their subject, which correlates with specific interdisciplinary constellation; (ii) and a multilayered commitment to imperial agendas, some exogenous to the geographic region and some not. Tracing diverse theoretic perspectives in adopting the concept of 'literary space' (as a driver of imagination, as a field of interaction, and as an ambient of non-occurring events), and minding the mentioned shortcomings, I come to a set of prospective research issues which, as I believe, can bring a scholarly field to birth.

Keywords: Autonomy of Research, Black Sea Studies, Literary Space, Marginalisation of Humanities, 'Subalternisation' of Unimportant Others.

\section{Introduction}

In the spring of 2018 a conference call for papers was issued under the promising title "Black Sea as Literary and Cultural Space" (with some variations in the title across the main organising institution's website ${ }^{1}$ ). The text of the call (Nuselovici and Dokhturishvili 2018) disappoints with the lack of critical focus, thematic omnivoraciousness and postmodern commonplaces (deterritorialisation, (post)transnationality, multiculturality) that, inter alia, fail to address, or figure out, the region's individuality; and any region's individuality. The main body of the text is based on an optimistic, simplifying and teleological postmodern narrative on how things have happened in comparative literature which used to be methodologically nationalist but later it liberated itself. It remains unclear how this universal treatment of our days ('be transnational in focus!') can be helpful in addressing literatures that have never been juxtaposed before, even within the framework of rigid methodological nationalism(s). However, the call brings to the fore a usable concept, 'literary space'. The book of abstracts (Black Sea Littoral 2018) contains some promising research proposals but fails

\footnotetext{
*Associate Professor, Division of Comparative Literature, Bulgarian Academy of Sciences, Institute for Literature, Bulgaria.

${ }^{1}$ Compare (CODFREURCOR 2018) and (Ilia State University 2018).
} 
to orchestrate a focussed whole. I will briefly defend my contentions below; here it would suffice to say that the mentioned shortcomings reflect the state of the art in the field, or in a field in its prenatal state; and that a proceedings volume might necessitate modifying the stated contentions but could neither replicate nor check the preliminary considerations that follow.

This article is written from the standpoint of a literary scholar who is aware that its topic is situated at the intersection of... geography and a number of other disciplines, most notably: history, linguistics, anthropology, cultural studies and, one among others, literary studies. Yet the concept of 'literary space' seems to me a convenient tool to evoke interdisciplinary research that has its focal point (or area) in (or about) literary studies; and hence potentially contributes to overcome a state of the art which perpetuates the position of Black Sea studies at the margin of humanities. In the first section of my article, I will introduce to the state of the art in Black Sea studies which I view as a scholarly field in a prenatal phase, in order to contextualise and support my claim that 'literary space' and 'cultural space' could be the conceptual tool to bring the mentioned field to birth. In its second section, I will relate my intuitions about polysemy of 'literary space' to previous uses of this concept by scholars ${ }^{2}$ and will briefly approach some potential or actual issues of the hypothetical field of Black Sea studies adopting the respective explications of the concept.

\section{Black Sea Studies and Humanities: Drafting the State of the Art}

The region's minor and unapparent otherness with regard to Europe/North Atlantic West, partly grounded in the lack of apparent subjection to European colonial powers of modernity, is precisely what makes research on it, in a postmodern/postcolonial context, especially challenging. There are both theoretical and empirical reasons to think that most voices coming from it, and their hypothetical choir (harmonious or cacophonic), seem not enough alien or enough (demographically etc.) significant to be let, or invited to, sound. In brief, they do not speak for anything like the 'Global South'. They are let sound in the way Europe's own periphery is let: in the sub-modes of (self-) deconstructing nationalism ${ }^{3}$ and of deconstructing renascent imperial aspirations. ${ }^{4}$ The former

\footnotetext{
${ }^{2}$ As a rule, I shall omit works which used the concept without defining it, as if a common language expression. I myself shall be using the concept in the same way in the first part of the article. I also exclude from consideration strings of works, mainly in Slavic studies, which use the terms "chronotop" and "chudožestvennoe prostranstvo", the former coined by Mikhail Bakhtin and the latter sanctioned probably by the medievalist Dmitriy Likhachëv.

${ }^{3}$ As are Bulgarian, Greek and Romanian discourses in the volumes of Entangled Histories of the Balkans (I deliberately refrain from full reference).

${ }^{4}$ It is a tacit assumption of the two last sentences above that scholarship from and on nation-states in Europe's periphery has only the two mentioned options for ideological and methodological framing of its occupations, if this scholarship wishes to be published by renowned journals and publishers. And that scholarship devoted to the European core and to the 'Global South' has more options. Reasons for this divergence of possibilities are embedded in the structure of the international scholarly field and its entanglement with political and economical structures and agencies. The issue is intimately tied with the topic of the present article, but addressing it needs a separate one.
} 
sub-mode is felt in Neal Ascherson's (1995) and Charles King's (2004) histories and in the Southeast European and Black Sea Studies editorial instruction to authors to avoid ethnocentrism (SEEBSS n.y.) ${ }^{5}$. The latter sub-mode is felt in variegated criticism of Russian imperialism (for example, in the seminal work of Susan Layton [1995]) and of neo-Ottomanism. A work approximately coeval to the first moves of neo-Ottomanism (on them see: Çolak 2006), seminal study by Eyup Özveren (1997), discussed below, tellingly models the period following Ottoman hegemony as (the) one to be emulated. King's 2004 history of the sea lacks such bent or sympathy and indirectly and unintentionally aggrandises the period of Ottoman hegemony. ${ }^{6}$

Metageographical stereotypes ${ }^{7}$ and the realities of the Cold War should have had stagnating effect on a notion of Black Sea space (as a driver of imagination, as a site of interaction, and even as an ambient). Post-Cold War policies of gaining favour, or ingratiating, with the West prove as no less destructive (King 2004: $\left.239^{8}\right)$.

Recent attempts at thinking the countries/communities/societies around the sea not separately but as an interrelated whole ${ }^{9}$ can reiterate the Cold War divide, ${ }^{10}$ just as numerous works on Russian military and political expansionism/ revisionism do it.

It is my impression that in recent research four kinds of works seem to prevail: geopolitics; economy; practical sociology and political science ${ }^{11}$; prehistoric and ancient archaeology. The disciplinary scope of the probably only international academic journal to contain "Black Sea" in its title, Southeast European and Black Sea Studies (associated with the Hellenic Foundation for European and Foreign Policy), and of the probably most long lasting book series to contain it, Black Sea Studies (issued by the Danish National Research Foundation's Centre for BSS), epitomises the status quo. To put it otherwise: research on BS is either completely torn from current economic and political

\footnotetext{
${ }^{5}$ The journal is published since 2001 .

${ }^{6}$ As for mid-sized powers, represented by the nation-states of the region that lack imperial past, it seems that their moral and intellectual capital to decolonise themselves has been entirely spent in and devoured by the rise and moral/symbolic fall of nationalism, between early $19^{\text {th }}$ and late $20^{\text {th }} \mathrm{c}$., so that the only source of credit for their self-perpetuating agency, apart from post-modern (self)deconstruction of nation and at least moderation of nationalism, remains Western scorn for regional former empires.

${ }^{7}$ See (Lewis and Wigen 1997); but also, in particular, geography of prestige associated with EU enlargement.

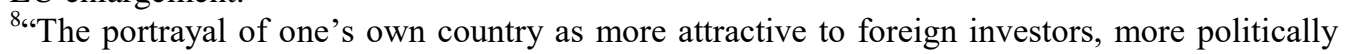
stable, even more civilized than those just down the coast has remained the normal mode of discourse. Today, there are few places in the world where political elites and average citizens know less about their neighbours than around the Black Sea".

9"The objective of the workshop is to develop the idea of the Black Sea littoral as an international meeting place of the socialist world". This is an excerpt from a workshop call for papers, "The Black Sea in the Socialist World", which was to be held in February 2015 in the University of London (Conterio 2014).

${ }^{10}$ Why not thinking of sides across the divide juxtaposing them, hypothesising, for example, their mutual complementarity, no matter successfully or not?

${ }^{11}$ E.g. studies of implementability of modern Western political and societal culture in mainly post-Soviet settings.
} 
agendas, or overtly perceived as instrumental to them (the confession in Sideri and Roupakia (2017: 24) ${ }^{12}$ is indicative).

Such a constellation keeps a notion of a Black Sea space outside the core of humanities reproduced through a general humanitarian education (in secondary school and university courses for non-specialists) and epitomised by literary studies. ${ }^{13}$ Focus on social sciences and ancient history/archaeology (disciplines that are closest to viewing their subjects as natural objects) maintains, in the academic space, a 'nomothetised' - a moderately dehumanised - image of the Black Sea area and its inhabitants. It/they largely remain(s) outside the scope of 'ideographical' ${ }^{14}$ inquiry.

The journal Karadeniz-Blackseа-Черное море ${ }^{15}$ can be viewed as a challenge to the above outlined interdisciplinary constellation. It is issued quarterly since 2009 by a Turkish publishing house ${ }^{16}$ is worth devoting a separate article to. Here, the disciplinary context is one of social sciences (which are designated as the journal's "subject" in CEEOL) and (actually to no lesser extent) humanities. I will restrict myself to a brief analytic summary based on ten issues from the 38 available at CEEOL (Karadeniz 2009-2018): the earliest four (2009), four from 2014, and the latest two (2018).

Within the first issue, if a Black Sea area surfaces at all, it appears not like a site of contact but as a site of repressed 'Turkish-/Turkicness' ${ }^{17}$ that is under revival through the research published in the journal. There is no editorial, to explain the name and programme of the journal. Authors are Turks and Turkic ethnics from Russia ${ }^{18}$, later from Azerbaijan and Kazakhstan too. Two articles are published in Russian, while the rest are in Turkish. Some of the summaries are hard to understand due to the quality of their English language. Throughout this and next issues BS appears as a contact zone, in both spatial and symbolical terms. In this zone two kinds of 'Turkish-/Turkicness' meet: of Turkey and of a space comprising Eastern Europe ${ }^{19}$ and Inner Asia. Already in the third issue two articles were published which forged a cross-BS Turkic interliterary space. Greek and Armenian presence in the history of the region was tacitly circumvented, while the two articles within the journal's first year

\footnotetext{
12، As the Black Sea region represents Europe's borders to the East and also the space where European identities and borders have been challenged through various types of migrations as well as enlargement, we hope this collection of essays becomes a useful tool for all those interested in contemporary politics - and EU politics more specifically".

${ }^{13}$ I view literary studies as the core of humanities because it seems to me that literary studies' subject, literature, converges art, (verbal) language and ideology in the most balanced and far-going way, in comparison to historiography, visual arts etc., probably with the exception of theatre and cinema. This assessment rests on the intuitive assumption that the multitude of possible subjects of 'idiographic' inquiry (see the next note) can be viewed as sharing 'family resemblance' based on three features the combination of which grasps the nature of human species and the uniqueness of its representatives: 'artistry', 'lingualness' and 'ideologicity'.

${ }^{14}$ I recall here Wilhelm Windelbandt's basic typology of sciences.

${ }^{15}$ Note the morphological 'Turkification' of the name of the sea in English.

${ }^{16}$ See (CEEOL 2019). I was unable to obtain more specific information.

${ }^{17}$ It is an ambiguity supported by the formal identity of terms in the Turkish language.

${ }^{18}$ With one apparent exception, a Russian Turkologist of Russian or Ukrainian ethnicity.

${ }^{19}$ Esp. but not only Crimea and Tatarstan.
} 
which mentioned Christianity in their summaries (half-pronouncedly) introduced it as an exogenous agency in the region.

Moving to 2014, no. 1, apparent change is brought about by inclusion of English-language articles ${ }^{20}$ and of Georgian author (who publishes in Turkish). At first sight, language shift can be viewed as move towards further internationalisation (even globalisation) of the journal. Yet it is noteworthy that Russian authors appear more inclined to switch to English. This models an implicit hierarchy of languages of publication: English (worth switching to), Turkish (maybe worth switching from), and Russian (surely worth switching from). Cooptation of author from Georgia indicates and nurtures the same hierarchy, probably driving Turkish closer to the top position of English and promoting it as regional lingua franca (instead of Russian). ${ }^{21}$ In the second issue we see Siberia and the Asian Far East included in the symbolical geography of 'Turkish/cness'. In the third issue, an article contributes to the following turn in forging a (cross) BS literary space: a national of one BS country (Turkey) writes about the literature of another BS country (Russia). It is a rare approach on the pages of Karadeniz, but it is expected, for it adds another aspect to a desirable, from Turkish standpoint, hierarchy in distribution of knowledge. If Turkish is to be the lingua franca of the region, Turks have to be (the experts) in things about the region, while non-Turks can be just experts in their national matters ${ }^{22}$. I did not notice a reciprocal contribution: it seems that Russian specialists in Turkish literature publish elsewhere. A similar contribution, "Myth of Sacrifice' in the Texts of Russian and Bulgarian Literature", is published in the latest issue available through CEEOL $(2018: 2) .{ }^{23}$ The text of the English abstract gives reasons to think that the author read her Bulgarian source(s) not in the original but in Russian. If I am right, the aforementioned hierarchy of languages is extended: medium-sized vernaculars from the region are at the bottom so far (the case of Georgian scholar writing in Turkish). ${ }^{24}$

Moving to 2018, no. 1, I find noteworthy the focus on Anatolia and archaeology, and the disappearance of Turkic authors from Russia/former USSR. ${ }^{25}$

Characteristically enough, while not successful in forging an international/ transnational BS region, or in constituting such a region as a frame and unit of analysis, the journal fails to address an eponymous territorial entity too. I mean the so called Black Sea Region of Turkey, one of the administrative divisions

\footnotetext{
${ }^{20}$ By a Turkish and by Russian authors.

${ }^{21} \mathrm{My}$ conclusions rest on numerically scarce data. Hence they can be factually misleading. Whatever the case, I insist on the theoretic significance of applying such an approach to a scholarly journal and its languages.

${ }^{22}$ Compare with the global stance of Anglo-American, and partly French, German and Russian, academia.

${ }^{23}$ After the present article was submitted, no. 1 for 2019 of Karadeniz appeared at CEEOL. I cannot comment the contents of this issue.

${ }^{24}$ Practicalities should not be ruled out: creating of research centres promoting acquisition of regional vernaculars and knowledge based on surveying sources in the original language consumes time and resources. Publishing in languages with drastically lesser number of speakers than Turkish poses other challenges...

${ }^{25}$ As witnessed by the list of authors in no. 2 , the mentioned disappearance was a temporary one.
} 
of the Republic. Studies of sites, events and phenomena related to BSR territory are too sparse across the journal. While produced by academics from the this very region, it remained entrapped in a paradigm of excavating 'Turkishness outside Turkey' and thus remained a Turkish national edition, one expressing attitudes linkable with the ideologies of Pan-Turkism and, to a lesser extent, of NeoOttomanism.

An article published in the journal's second issue (2009: 2), under the title “The name of 'Kara Deniz': a view from Caspia and Bulgaria”, epitomises the stance of symbolical (re)appropriation of the sea on behalf of (a) Pan-Turkism:

In searching for roots of the denomination "Black Sea", which today has a universal popularity, researchers immediately refer to the Anatolian Turks as the main and easiest source [...] The Anatolian Turks were not first to use the 'black' form, and could not be source for other nations for chronological and historical reasons. Source of this name, which was spread as far as Iceland at the very beginning of its occurence in sources, is again Turks, but we need to have a glance at Bulgar and Khazar worlds. This essay claims that the "black" in the Black Sea is likely included in the Bulgar legacy of the region. (Karatay 2009).

It is noteworthy that Karatay (2009: 67-69) does not circumvent the Iranian interpretation (authoritatively articulated by Schmitt 1989) but downplays it (not mentioning it in the abstract). Downplaying is symbolically/politically relevant. As well-known, history of Black Sea can be viewed (and is usually viewed) as NorthEastern extension of the Greco-Roman one: the sea is being discovered by ancient Greeks and thus is being included into history sensu stricto, and so on. There are reasons (archaeological evidence etc.) to model a history of BS from Iranian standpoint, from the perspective of Iranian 'oecumene'. A Turkish/Turkic-centred history is a third broad-scale option. Editors of Karadeniz come close to a paradigmatic shift in Black Sea studies, albeit clumsily: demonstrating political engagement and no reflection on the political relevance and on the reflexivity ${ }^{26}$ of their enterprise.

KAREN (KAREN 2015-2019), issued by the Institute of Black Sea studies of Karadeniz Technical University in Trabzon, is another Turkish journal worth paying attention to in this article. ${ }^{27}$ The name of the journal is derived from the Turkish-language abbreviation of the issuing institute. ${ }^{28}$ It also lacks a programmatic editorial (or it cannot be found, as the first issue altogether). The only

\footnotetext{
${ }^{26}$ Circular relation between them and their research subject.

${ }^{27}$ All seven, actually six of seven, issues are freely accessible at journal's website (see "Archive").

${ }^{28}$ Block letters are used by journal itself, see http://www.ktu.edu.tr/karenjournal. The name is an abbreviation based on the phrase "Institute of Black Sea Studies" in Turkish, "Karadeniz Araştırmaları Enstitüt" (relevant letters italicised by me). However, the journal itself offers a slightly different reading: "Karadeniz Araştırmaları Enstitüsü Dergisi (KAREN)/ The Journal of Institute of Black Sea Studies" (http://www.ktu.edu.tr/karendergi). One word, "dergisi” ('journal') apparently does not contribute to the abbreviation. Apparently, "KAREN" was found enough suitable. I am tempted to suggest than not only euphony was a criterion. The name of the journal coincides with an Armenian male name, "Karen". Incomplete coincidence does not indicate symbolic appropriation but symbolic displacement.
} 
article in its "current",29, seventh, issue - which addresses a Black Sea space within the field of humanities - performs, at the same time, a symbolic retroactive appropriation of a territory across the sea, as seen from the title: "A Look at the Social, Cultural, Economic, and Religious Development of Crimea during the Seljukian Era". The second issue contains four articles with local focus, on Trabzon, from the fields of archaeology, history, political science and applied sociology. As in the current issue, the only text which explicitly thematises a Black Sea region/area is devoted to geopolitics and scramble over hydrocarbons, viewing that area as a zone of contention between Russia and the West (Turkey being either a part or an ally of the West). In the third issue the mentioned strategy of (re)appropriation is typified by a fragment from an article's summary: "The peninsula located at the Northern Black Sea is called Crimea. Turks living there are called Tatars." (KAREN 2017, 1: 16 $6^{30}$ ). The issue (as well as the subsequent ones) retains the localist archaeological-historical focus on Trabzon (and, partially, Pontus: Giresun, Samsun, Rize etc.). It backs up preoccupation about contemporary Russian "revisionism" (in no. 2) with an investigation of a late $19^{\text {th }}$ century Russian plan to capture Istanbul. An article from the fourth issue devoted to a poet from Borchalo, an area in South-Eastern Georgia, extends the logic of (re)appropriation towards Caucasus; difficult to follow as it is, the wording in the summary's initial sentence suggests Turkish autochthony and Georgian exogeneity in the mentioned area: "Today it ["Borchali", sic] is divided into different regions and borrowed under the administration of the Republic of Georgia, living as an old Turkish homeland from old dates." (KAREN 2017, 2: $\left.14^{31}\right) .^{32}$ The last three issues add nothing substantial to the journal's profile.

Despite declaration that "KAREN is an international peerreviewed journal indexed by Index Copernicus" etc. (KAREN 2019, [1]: [3] ${ }^{33}$; emphasis added), the overwhelming part of the articles is written in Turkish and by Turkish scholars - just as is the cast of the editorial and advisory boards. Despite introducing the fashionable requisite of ORCID numbers alongside author's names, publications overwhelmingly address Turkish themes and conceptualise them ethnocentrically. It fails in constituting and even demarcating a BS region as a unit of analysis. ${ }^{34}$ But it succeeds in substantiating, in quantitative not qualitative terms, a territorially narrower prospective unit of research, the BS littoral of Anatolia (or "Black Sea Region" in Turkish administrative terms).

\footnotetext{
${ }^{29}$ Actually, it is the current, seventh issue; clicking on the link "Vol 1-1" at http://www.ktu.edu.tr/ karenjournal-archieve (Accessed 15.7.2019) leads to the same text as clicking on "Vol 5-7".

${ }^{30} \mathrm{http} / / /$ www.ktu.edu.tr/dosyalar/karendergi_30b43.pdf (accessed 15.7.19). I deliberately refrain from referencing the author of the article which contains the cited statement, preferring to view the statement as 'institutional'.

${ }^{31} \mathrm{http} / / /$ www.ktu.edu.tr/dosyalar/karendergi_ab1c0.pdf (accessed 15.7.19). I deliberately refrain from referencing the authors of the article which contains the cited statement, preferring to view the statement as 'institutional'.

${ }^{32}$ Overall, two attempts by Turkish scholars to address medieval Georgian history are to be found in the journal; yet their summaries provided me no reasons to consider them anything more than extensions of research in Turkish/Turkic history, they lack both regionalist and Kartvelological focus.

${ }^{33}$ http://www.ktu.edu.tr/dosyalar/karendergi_df374.pdf (accessed 15.7.19).

${ }^{34}$ It 'fails', if we assume that a corresponding intention existed at all.
} 
A research group at Columbia University, ${ }^{35}$ calling themselves "Black Sea Networks" and devoting themselves to the "collaborative initiative to investigate the Black Sea as a hub of cultural, political, and historical interest", for now seem to only demarcate a research territory and academic niche (prospective master's and doctoral programmes in 'BS s/Studies' etc.) (Black Sea Networks 2019). A mere list of participants and a brief declaration of intention are hard to assess, yet in this case two peculiarities provoke comment. First, a neo-colonial structure of the research enterprise is suggested: a prestigious Western institution shapes a team abundant in affiliated and non-affiliated natives of the off-shore territory which constitutes the research object. Second, an interdisciplinary compromise, balancing between mainstream interest in political phenomena and marginal humanities, is offered. Both peculiarities promise too timid a departure from, and maybe even a reiteration and strengthening of the state of the art in the field. The multileveled neo-colonial power relations that shape international distribution of academic labour, that are embodied in a hierarchy of exogenous standpoints and institutions ${ }^{36}$, and that shaped the interdisciplinary constellation outlined above would be embodied in a collective agent at the highest hierarchical position ${ }^{37}$. And these relations would be projected into the up to now missing disciplinary core (non-applied humanities and non-applied literary studies in particular). ${ }^{38}$

As already noted, Karadeniz and KAREN make partly visible and are possibly committed to a self-empowering, self-exalting and self-exempting vision of the region; the same could be argued about SEEBSS (although the aspiring agency is less easily identifiable and the aspiration far less pronounced). Let us call this kind of agency (neo)imperial. It embodies a certain structural tendency, hinted at in the previous paragraph: the tendency of 'externalisation' of authoritative knowledge on the region. The "Black Sea Networks" the structural possibility of a neo-colonial agency. I would provisionally define a (neo)colonial agency as a(neo)imperial one with substantial offshore possessions. Its main characteristic relevant to my argument is extraterritoriality; or principal exogenousness, if conceived from the standpoint of the offshore possession, BS region in our case.

\footnotetext{
${ }^{35}$ Actually 5 of 12 members of the "core team", incl. the "principle investigator", are from Columbia University.

${ }^{36}$ The farer is an institution the more prestigious is its opinion. It would suffice to add here that such symbolic geography is unalienable from collective imagination in societies undergoing either Europeanisation or de-Sovietisation and that most BS societies undergo both processes (Turkey of AKP being the sole regional agent which probably is more or less free from both self-colonising discourses).

${ }^{37}$ This agent is or will be internationally visible par excellence, which exactly matches the neocolonial power relations in and outside academia.

${ }^{38}$ After this article has been submitted to peer-review, brief bios of the members of the "core team" of the project appeared on the website. The project website could have systematically indicated those research achievements and interests of the project participants which back up their participation in the project. Whatever the case, it is possible to analyse individual research records in order to make prognosis on the group's prospective activities more accurate; but this would have been an undeserved tribute to a reputation.

${ }^{39}$ It remains unclear why plural is used.
} 
Tendencies towards 'exogenisation' of authoritative knowledge and 'nomothetisation' of the subject of research in scholarship on societies etc. around the Black Sea are deeply congruent to each other.

Homo ponticus, if such exists (=can be plausibly evoked to existence by scholarship), has still not been invested the constitutive properties of modern humanity (and it is them that position him/her on a par with any contemporary scholar - howsoever 'post-modern' the latter may conceive of himself), his/her humanity found/projected into/associated with pre- and postmodernity. This is so even if we count for the possibility that some communities less than other lean to put their experiences into literature (just as some seem to be less leaning to represent/experience sea as domestifiable space).

In particular, we still lack a volume on Black Sea literatures to bring together "articles on the development of the various literatures or parallel phenomena in them", even less one to indicate "any explicit relationships or contrasts among the different traditions". (I cited past conclusions of Hilary Kilpatrick (2000: 83) which addressed the state of the art in the study of Near ${ }^{40}$ Eastern literatures). Kilpatrick does not focus on another aspect of the situation, no less valid for the hypothetic field of BS studies in humanities.

In line with the international division of academic labour, whereby the periphery is assigned (or assigns to itself) only occupation with one's own (still national) self and with the most prestigious international core, research on BS region in BS countries even lacks institutionalised forms. Such state of the art gives some reasons for more far-going scepticism on the prospects of cross-Black Sea regional integration than the one expressed in (Manoli 2010) ${ }^{41}$. On the other hand, interpreting (physical and mental) artefacts related to places within the BS basin as artefacts signifying a Black Sea space could be prone to nostalgic imperial agendas, as is the case, for example, with Karadeniz.

A recent collective research project on the BS region demonstrates concern with viewing $18^{\text {th }}$ and $19^{\text {th }}$ centuries links between Europe and Black Sea societies and cultures as links of [bi-directional] exchange, not of [unidirectional] transfer (Kaser and Gutmeyr 2018: 17-20). Such a concern is justified by new data on how 'the things were', but it has a normative force too: one apparently related to reluctance to reiterate colonial power relations through the means of scholarship. One wonders whether we can extrapolate this normative framework to our contemporaneity, arguably characterised by post-, counter- and non-nationalist / post- etc. ethnocentric scholarship predominant in the West and, arguably, resistant nationalist / ethnocentric in countries around the Black Sea. One wonders whether encouraging non-ethnocentric research on BS issues contributes to knowledge transfer (which is unidirectional) rather than exchange. One wonders why $18^{\text {th }}-19^{\text {th }}$ century locals are recognised as holders of knowledge to be shared and early $21^{\text {st }}$ century ones are not. If in position of academic publisher, I would

\footnotetext{
${ }^{40}$ I insist on the appropriateness of this denominator, instead of "Middle".

${ }^{41}$ Tacit teleologism and geopolitical/geocultural bias in Manoli's article ("Yet, to date there is still no blueprint for Black Sea regionalism to deepen cooperation and integrate into the European community." [2010: 323 (abstract)]) presents another problem, possibly typical for the majority of studies on the region, which, however, I prefer to not comment here.
} 
abstain from discouraging ethnocentric studies in favour of non-ethnocentric, being aware that, a century or more ago, it was ethnocentric - in the sense of nationalist and in the sense of Eurocentric - knowledge that was transferred into the region, being reputed to be advanced.

It can be argued that it would be premature to deconstruct ethnocentric scholarships from the Black Sea region before even letting them share a common stage and ground; whether we wish that or not, scholarship in and beyond the region is organised along national, that is, cryptoethnic and (crypto)ethnocentric, lines, the same being with various societal structures; despite globalisation. Yet two of the too few histories of the Black Sea - King's and Ascherson's - seem to take this arguably premature stance. Intersubjectivity prior to subjects, or, rather: transnationality prior to internationality, transsubjectivity prior to intersubjectivity seems the overarching epistemic filter in these works. From appreciating vernacular cosmopolitisim to championing the current (neoliberal, EU or else) one, circumventing imperial and especially nationalist legacies as burdensome, probably with the tacit excuse that marine space, unlike land-locked, marginalises 'vernacularist' ideologies ${ }^{42}$ like nationalism from the outset. ${ }^{43}$.

These considerations hint at the possibility of making a scholarly use of focus on BS (region) that goes beyond justifying and researching the subject (BS, or BS region) itself. That is, scholarly research on 'things Black Sea' is not only a goal in itself (especially provided that Black Sea region proves a viable unit of analysis) but an opportunity to challenge metageographical stereotyping; and to challenge the monologue for two voices involving Eurocentrism and its postcolonial others.

In a way, Ascherson follows the specific logic of Russian Orientalism in the Caucasus: dividing the locals into interesting (and noble) savages and not-sointeresting (and not noble) (quasi)civilised Orientals; a divide noticed by Susan Layton (1995); unpremeditatedly, he falls into the monologic discourse of colonists vs nomads, civilised vs barbarians and... Greeks vs Scythians. Russians, Byzantines of Trebizond and Poles fit the first; Khazars, Tatars and Abkhazians the second category. Many of those who fit in neither remain outside the story. The Crimean Karaims are actually the only exception in Ascherson's book.

Hence research focussing on interactions between more than two kinds of actors, ideally to implement and extrapolate the fourfold sociolinguistic typology of Henri Gobard, is desirable. Binary structuring of the object reinforces 'civilisational myopia'. The latter seems to be one of the properties of general historical writing about BS. It comes to testify that the use of postcolonial/ postmodern analytic repertoire is selective. What people knew about an object implicitly coincides with what ancient Greeks-and-their-intellectual-heirs-in-theWest knew (as in King 2004: 12-13). Greater cultural mixing between Greeks and

\footnotetext{
${ }^{42}$ Referring to the sociolinguistic typology of Henri Gobard (1976; discerning four mutually complementing functions of language: vernacular, vehicular, referential, mythical), I demarcate the possibility of considering nationalism as an ideology that forges a societal etc. order through overestimating 'vernacular' values and artefacts. It seems possible to chart a typology of ideologies basing on their privileging one or another function of language and prescribing a relevant world order.

${ }^{43}$ A sentiment against 'terrestrial order' is felt in Ascherson (1995: 274-275) (“[...] But it is a thought from inland [...]"); in the book of King - in subtler, diffuse, ways.
} 
barbarians is explained with hypothesised higher level of development of "civilisations and political structures" of some of the barbarians (King 2004: 34); the explanation depends on implicit assumptions too. The myopia has both epistemological and axiological dimensions.

What lies on the surface as a tool of knowledge is taken as if by default as the best /only possible/frame-forming tool; namely, the Greek and Roman written sources. As a result, BS is depicted as the north-eastern fringe of Hellenic and then Roman civilisation; instead of being depicted as the south-western fringe of the Scythian/nomadic/steppe nomos, ${ }^{44}$ the western of the Iranian one,${ }^{45}$ or the 'door' for the Caucasian cultural community to marine interaction... A history to reckon all the mentioned perspectives would fit an important methodological requirement of Westphal's geocriticism (on geocriticism see below, section 2) and could be viewed as its extrapolation from literary into cultural studies.

Given the precedent of Nikolay Trubetskoy's View on Russian history not from the west but from the east (1925), the lack of 'geo-optical' daring in a history written in the 2000s is even more disappointing. On the other hand, to write a history of BS against the almost complete lack of precedents is already a feat. Yet what would constitute a breakthrough is any attempt to write of BS places, events, and artefacts from the perspective of nomoi different from the Greco-Roman and the European ones.

Civilisational egocentrism on behalf of a West tracing its genealogy to ancient Greece $^{46}$ pervades even writing that consciously tries to count for the lopsidedness of the 'Hellenes vs. barbarians' divide (and its derivatives). The intellectually prudent and grammatically correct sentence "As is well known, from the remotest Antiquity the indigenous and nomadic non-Greek populations of the Pontic region were persistently viewed as one of the major 'Others' (e.g. Hartog 1980)" (Bilde and Petersen 2008: 9) tellingly lacks a grammatical object specifying the subject of perception, or, to put it otherwise, the 'locus of enunciation'. Viewed by whom? Why someone's standpoint is so powerful that it even does not require explication? Such is the power of discourse. Next, to recognise that an encounter is transformative for those who meet, that no one of them is superior, and that no one of them is deserving more attention are (three) different things, but Bilde and Petersen (2008: 10) seem to overlook the difference.

I attempted a preliminary epistemological contemplation on the tacit assumptions in, and to some extent the repertoire and the methodologies of, Black Sea studies. I shall try to explain now why and how introducing the concept of 'literary space' in these studies could stimulate epistemological self-awareness in them and help overcome an unfavourable interdisciplinary (and institutional) constellation which deprives regional academia, intellectual elites and, ultimately, societies from cognitive and historical agency.

\footnotetext{
${ }^{44}$ As partly implemented in (Vinogradov 2008), who reckons with the validity of "a pattern of historical development for the region which differs from the customary division of ancient history into Archaic, Classical, Hellenistic and Roman periods" (13).

${ }^{45}$ As initiated in (Nieling and Rehm 2010).

${ }^{46}$ No matter which: of "wartime intellectuals [...] in Athens" or of "Ionian colonists at Olbia or Chersonesus", to use Ascherson's dichotomy (1995: 275).
} 


\section{Explanations of the Concept of 'Literary Space' and Respective Black Sea Studies Prospects}

Taking the standpoint of what seems to me common reason (albeit one shaped by philological education), I understand literary space to be trifold:

(i) A product, matter and, possibly, a driver of (literary) imagination;

(ii) A site of interaction between literatures, potentially leading to or, possibly, a symptom of the existence of what theory has called "[inter]literary centrism", "interliterary community" (terms of Dionýz Durišin) ${ }^{47}$ or even "world-literature" (understood as analogue of Braudel's "world-economy", see Domínguez, Saussy and Villanueva, 2015: 36);

(iii) A site of mere collocation of literatures.

Hence: a myth, a field of powers, and an ambient.

The first perspective on 'literary space', the one that models it as 'myth', can probably be best supported by the notion of 'literary space' worked out in "literary geography"; a subdiscipline or scholarly practice that has been developed within the confines of British cultural geography for decades (see Hones 2008: 13031305, 1312-1313 and 2010, 2014: 164, 169, 170). Literary geography "regards texts as events that happen in the course of sociospatial and intertextual interactions" (2014: 11); while literary space is viewed here as the dynamic simultaneity provided by intertextuality within a text $(2014,17)$. It is considered not only as an entanglement of fictional and factual whence neither can be given prominence (2014: 12-13, 108 etc.) but also as a phenomenon which is unmappable (117).

To say it otherwise: a space becomes a literary space when its representations and knowledge production about it can and are analysed with the tools of narratology, hopefully one that had overcome the notion of space as 'container' (compare Hones 2008).

Basing "literary geography" on understanding of space not as a "grid", "container" and setting but as process(ual) ${ }^{48}$ (2011: 686-688; 2014), Sheila Hones apparently (2014: 170) denies that such understanding is mastered by the more recent projections of literary studies into the field of geography. The latter are exemplified by Franco Moretti's Atlas of European Novel and Bertrand Westphal's Geocritique. It seems that the main criticism against Moretti is that he gives ontological priority to 'factual' over 'fictional'; against Westphal - that, despite

\footnotetext{
47، A 'specific interliterary community' refers to the coexistence of several literary systems whose level of interaction is close to that of national literatures [to that within a national literature]", unlike a "standard interliterary community". "Literary centrisms" are defined by Ďurišin either as "regional bodies larger than communities" or as "communities that play a large-scale integrative role" (Dominguéz 2012: 103; [rephrasing] added).

${ }^{48}$ But also omnipresent, with permeable boundaries, and plural/heterarchical (Hones 2010: 61; after Thrift 2006).
} 
due acknowledgement of the co-formative power of "fictional" ${ }^{49}$, he understands space as a measurable container.

Seen from this perspective, a BS literary space could be and will be discernible on the condition that insights and the methodology of literary geography are implemented. Within such context, the issue of whether an experience of literary space can be put on a map ${ }^{50}$ seems to have secondary importance; deliberation whether it exists or not would have a primary one.

Understanding of literary space within literary geography of geographers shares a basic intuition with an earlier conceptualisation within the field of literary studies. It can be viewed as unpremeditated concretisation of the intuition (Jacobsen 1982) that a literary space is a (kind of) "potential space" as defined by the psychoanalyst D.W. Winnicott (1971). Mary Jacobsen shows that literary space is neither inner nor outer; that it cannot sustain claims for final truth or correctness; that it involves the readers into "willing" (non)-“suspension of disbelief".

In some partial way, the understanding of literary space as 'space-asorganised-by-rhetoric', or as the space organised by rhetoric ${ }^{51}$ (see Wooten 2000), also fits the perspective of literary space as a product, a matter and a driver of imagination.

Westphal's awareness regarding the historically changing gap between perception of space and representation of space $\left(2011: 57-59^{52}, 84^{53}-86,132^{54}\right)$ fits too. It lets view literary space as a magnifier and an obscurer of that gap and gap's change over time. Closer to the core of his theoretical project, we can view literary space as a tool for realisation, a specimen, a facet and maybe a concentrate of immanent intersubjectivity of any space. ${ }^{55}$ Thus, BS as literary space would be constituted through "an intertextual chain that will be consolidated over time and across many different books (or paintings, or films, etc.)" (Westphal 2011: 117-8) that refer to BS.

The second perspective on 'literary space', modelling it as a 'field of powers', is compatible with (A) an extension of Fernand Braudel's theory of historical space into literary studies (the extension prefigured by Dionýz Durišin's theory of interliterarity [Ďrišin 1989 etc.] and recognised by Cesar Domínguez [2012: 103]); with (B) adaptation of Pierre Bourdieu's sociology of culture to issues of

\footnotetext{
49،"G]eocriticism confronts a referent whose literary representation is no longer seen as distorting, but as foundational" (Westphal 2011: 113).

${ }^{50} \mathrm{~A}$ review of diverse approaches to this possibility from the domain of literary studies is offered by Urška Perenič (2014).

${ }^{51}$ As suggested by Greco-Roman sources and shared by at least some of the scholars in classics.

${ }^{52}$ If a representation of space can be "sclerotic" (57), it can be non-sclerotic too, and these can vary over historical time and cultural space. "In the Navigatio Sancti Brendani, no attempt was made to account for the physical, objective world, but only for a world designed by God and recognized by men" (57-58). The latter statement does not, of course, testify to a belief (on behalf of Westphal) that physicality of space/world was not perceived by St. Brendan.

53، Is mimesis always based on fidelity to appearances? [...] In postmodernity, the gap between the world and the text has been significantly reduced $[\ldots]$..

54، The dominance of the visual, which is actually more pronounced in discourse and metaphors than in perceptions $[\ldots]$ ".

${ }^{55}$ From the standpoint of geocritique or geocriticism, intersubjectivity or multifocalisation is that what makes space a space.
} 
comparative literature (as performed by Pascale Casanova [1999] 2007); ${ }^{.6}$ and with (C) the literary topology of Juan Bruce-Novoa (1975; 1988; 1990).

For Casanova and those who take her work, albeit with some criticism, as a point of reference (as Leypoldt, 2015; or Hibbitt 2017), literary space is a loose synonym for (inter- or transnational) literary field.

As for Bruce-Novoa, his "literary space" seems to be a dynamic constellation of works experienced in their relationship "to other texts and/or events which form and define their area of movement" - from other literary works to "oral tradition, film, music, history or multiple facets of social interaction" (1990: 158-159). Speaking of BS as literary space in the sense of Bruce-Novoa, and minding his reference to George Steiner's definition of culture ${ }^{57}$, would mean to hypothesise that a constellation of literary works exists which persists in time and can be labelled as BS.

Regarding studies of the BS, anticipatory to this perspective (to its first theoretical variant: Braudelian understanding of historical space) was a study by Yaşar Eyüp Özveren (1997). According to Özveren, Black Sea region was indeed a world-system within the global world-system, or world-within-the-world, during the long $19^{\text {th }} \mathrm{c}$., as far as material goods and financial capitals were concerned; that is, it existed as a supralocal entity and as a unit of analysis - economically. More important, a general conclusion could be drawn from the mentioned study that a 'supralocality' can exist as an entity impermanently, probably periodically: thus helping avoid regionalist/arealist essentialism. As far as I know, there are no works inquiring whether the historical condition described by Özveren is extendable to exchange of non-material goods (ideas, ideologies, images, attitudes) and of artistic and literary artefacts and models.

It can be argued that indispensable hints at how to probe the existence of a Black Sea interliterary space, or Black Sea world-literature, are to be found in works by Johann Strauss (2003 etc.) and Hilary Kilpatrick (2000).

The third perspective, supportable by findings that sometimes in a meeting between cultures neither acculturation nor transculturation ${ }^{58}$ can occur, would confront us with the insight that a non-event is also an event ${ }^{59}$ ); and would allow us admit that it is the structure of a certain space that welcomes - or not - one or another theory of space (primarily, grid vs. processual, i.e., 'space-is-out-there' vs. 'space is created through imagination and interaction'). An article in comparative literature (Ljuckanov 2014: 296-7) has expressed the caution that a BS interliterary space might turn, upon performing necessary research, a mere interliterary

\footnotetext{
${ }^{56}$ Casanova relies on Braudelian intellectual experience too (Hibbitt 2017: 9). An explicit preliminary theorisation on implementability of Bourdieu's theory of field in comparative literature see in Boschetti 2012.

57 "Defined 'topologically', a culture is a sequence of translations and transformations of constants" (cited in Bruce-Novoa 1988: 264).

${ }^{58}$ Brief discussion of the difference between the 'acculturation' and 'transculturation' perspectives see in Domínguez et al. 2015: 63-64.

${ }^{59}$ As historical introduction to the issue in BS setting may serve the article by Jakob Munk Højte (2008). Compare with more general scepticism in Ascherson (1995: 9): "But my sense of Black Sea life, a sad one, is that latent mistrust between different cultures is immortal".
} 
collocation. Yet it conveyed the methodological suggestion, or recommendation, not to rule out a story of non-success from objects of inquiry.

All conceptualisations of literary space referred to above can contribute in one way or another to better understand our material-ideal object, Black Sea; to unpacking it from political-economic and geopolitical uses, interpretations and concerns.

Focus on the 'literary' up to this point comes from the limits of my vocation. Yet I am aware that non-artistic and non-verbal manifestations of cultural spaces exist. A wide variety of tangible and intangible assets (from folklore to signs on money to eating habits to loanwords etc.) that are invested value within the broad zone of human agency inbetween/alongside economy and politics can stimulate imaginative coherence. The latter could be interlocal, intercommunal, interpolitical [between polities], international etc.; and it could be perceivable by locals, by outsiders or by both. ${ }^{60}$

As far as I can judge, the triple semanticisation of 'literary space' can be effectively extrapolated to the concept of 'cultural space'. The latter concept, if semanticised and used with the view of Pierre Bourdieu's sociology, could become a cornerstone for de-marginalisation, or indeed the bringing to birth, of a field. It would be a rigorist use that would abstain from studying political and economic phenomena and that would (deconstruct and) avoid political and economic concerns in the choice of research topics.

\section{In Lieu of Conclusion}

I would outline sets of research issues (I would not dare to say a research agenda), which set, if implemented, would bring a field out of its prenatal phase.

The following research desiderata can be a good starting 'intellectual site' towards the aforementioned unpacking and de-marginalisation:

- negotiating the notion of BS region as a viable unit of analysis in literary and cultural studies;

- elaborating the concepts 'literary space' and 'cultural space' based on material from literatures and cultures from the BS region;

- testing the workability of concepts 'BS literary space' and 'BS cultural space' (the whole set was more or less addressed by the paper proposals of Özveren (2018), Charriere (2018), Durnali \& Emeç (2018), Johadze (2018), Lomidze (2018) / Lyutskanov(2011) ${ }^{61}$, Mamatsashvili (2018), Sabatos (2018), Skvirskaya (2018) and Svanidze (2018) [abstract only in Georgian], and partly by a group of proposals using the thematic pattern

\footnotetext{
${ }^{60}$ But see also: the specific way in which literature (in comparison to music, architecture etc.) evokes space; or BS as space evoked by literature (and not music etc).

${ }^{61}$ This text appears as Gaga Lomidze's (2018) in the Abstracts of Communications brochure (https://iliauni.edu.ge/uploads/other/48/48797.pdf, 42) and as Yordan Lyutskanov's (2011) at "Academia.edu"(https://www.academia.edu/36548275/Comparative_literatures_of_the_Black_ Sea_region_Call_for_papers).
} 
'BS in the works of N', for the October 2018 conference, but the text of the conference call makes me believe that these papers will remain membra disjecta in the proceedings volume);

- addressing or drafting or preconceiving the differentia specifica of such a 'space', that is, implementing an ideographical approach (in the sense of W. Windelbandt) on the level of methodology from the outset.

The latter is what the 2018 conference call exactly failed to do. From the theoretical toolbox of postmodern/postcolonial studies it has chosen those which are likely to have universal applicability (hence we have the preconception of one more Carribean, one more Medditerranean, one more East-Central Europe... - one more site, still unoccupied, to try the toolbox). If the conference succeeded in something, this is to summon scholars with diverse backgrounds interested in contributing to a field that emerges.

Further on, focussing on the following set of issues related to the symbolical capital acquirable by scholars and communities of the Black Sea area to make a scholarly field worth existing, could be helpful:

- (in)coherence between written and oral sources on Black Sea related events, localities, artefacts etc (If BS is the "birthplace of civilisation and barbarity", why not considering it the birthplace of conflict of interpretations based on written vs. oral memory respectively?);

- (in)coherence between 'indigenous' and 'outsider's' preconceptions and interpretations;

- competing, conflicting, complementary and incompatible interpretations of mythological figures associated with Black Sea and foundational for Hellenic and European sense of cultural and interpretative superiority (see Beridze's paper proposal for the 2018 conference)

- analysing interactions between more than two kinds of cultural or societal actors within the Black Sea region / area, ideally to extrapolate the fourfold sociolinguistic typology of Henri Gobard ${ }^{62}$;

- performing expositions on BS places, events, artefacts from the perspective of nomoi (world-orders) other than the Greco-Roman and the European one $(s)^{63}$.

These issues would stimulate the mentioned scholars and communities conceive their own condition in terms of responsibility for voices that were silenced because of methodological and civilisational myopia.

Cross-Black Sea comparisons on any topic within any field of humanities are desirable at any moment. Cross-BS focus is likely to have a disciplining

\footnotetext{
${ }^{62}$ It views any linguistic situation as one of potential or actual tetraglossia, which is characterised by mutual complementarity of languages, as in diglossia (distinguished from bilinguism). Within tetraglossia, languages assume the functions of a vernacular, a vehicular, a referential or a mythological language.

${ }^{63}$ To turn again to the Tbilisi 2018 conference, such perspective is suggested by Licheli \& Guinashvili (2018) and by Margaryan (2018).
} 
effect, by circumventing the possibility of circumscribing research within already established domains like Balkan or Caucasian studies. Such comparison could be especially useful through performative deconstruction of the metageographical divide between a "Europe" and an "Asia". 64

Addressing a number of other issues could have a methodological and indeed epistemological disciplining effect on a scholarly community to come and could make it fit the reflexive character or ideal mode of social sciences and humanities, that is, the circular relationship between scholarship and subject:

- inspecting (in)significance of scholarship on enhancing/suppressing an idea of BS space and thus investigating the (prior) reflexivity of social sciences and humanities in the case of BS studies; ${ }^{65}$

- epistemological contemplation on (lack of) implicit civilisational bias, on the thematic, conceptual etc. repertoire, and on the methodologies in Black Sea studies.

The 2018 conference resulted from French-Georgian institutional cooperation. If it involves other institutions from the BS region as peers, it could turn into the appropriate institutional framework for the research field to be born outside the constraints of neo-colonial distribution of intellectual labour.

To summarise, prospective research on BS region should:

(i) overcome civilisational and epistemological myopia (which favours Eurocentric accounts based on written sources in Greek, Latin and Western languages);

(ii) evade monism (classificatory pattern based on the distinction between 'culture/civilisation' and 'barbarity');

(iii) make explicit use of the reflexivity of social sciences and of humanities;

(iv) be focussed on cross-BS research topics; and

(v) be supported by intraregional institutional cooperation. ${ }^{66}$

\footnotetext{
${ }^{64}$ Yet even cross-BS focus can depend on stereotypes undermining the nascent field from within, as critical analysis of conference held 10 years ago shows (Lyutskanov 2011).

${ }^{65}$ Considerations on applicability and desirability of applying the interpretative framework of Said's 'Orientalism', see Parastatov and Kondrasheva 2018: 314-315, could be a reference point, just as the diverging/converging reassessments of Byzantine, Ottoman and Russian imperial orders vis-àvis symbolic devaluation of nationalism in western scholarship. See also Ascherson 1995: 119-120: "Renate Rolle, the German archaeologist who is now the best-known Western interpreter of Scythian research in Russia and Ukraine [...] evidently felt that her image of Scythian girls trained to muscular and nervous perfection had to be walled-off from the contemporary triumphs of East German women athletes, hardened and unsexed by anabolic steroids. [...]”.

${ }^{66}$ The latter desideratum is well realised by Prof. Alexis Nuselovici, who pronounced and insisted on the idea of holding a sequence of conferences on BS region in countries of the BS littoral on regular basis (oral communication during the 2018 conference). (This note was added after the article had been reviewed).
} 
(vi) Region's experience as one that is (i) neither colonial nor metropolitan and (ii) neither 'European' nor 'non-European' still needs an adequate metalanguage to be worked out.

\section{References}

Ascherson N (1995) Black Sea: The Birthplace of Civilisation and Barbarism. London: Johnathan Cape.

Beridze K (2018) Translation in a Sense of Postcolonial Translation. In Black Sea Littoral as Literary and Cultural Space: International Conference (Abstracts of Communications). Research Center Romance intercomprehension. Intertextual dialogue, Institute of Comparative Literature of Ilia State University; Berlin Center for Literary and Cultural Studies; Center for Interdisciplinary Studies of Literatures at Aix-Marseille University; Tbilisi, 14-15. Retrieved from https://iliauni.edu.ge/uploads/other/48/ 48797.pdf. [Accessed 1 July 2019].

Black Sea Networks (2019) People. Retrieved from http://blackseanetworks.org/people. html. [Accessed 16 July 2019].

Boschetti A (2012) How Field Theory Can Contribute to Knowledge of World Literary Space. Paragraph 35(1): 10-29.

Bruce-Novoa J (1975) The Space of Chicano Literature. De colores 3 (1974-1975)(4): 2242.

Bruce-Novoa J (1988) The Topological Space of Chicano Literature. Revue Française d'Études Américaines 36: 263-273.

Bruce-Novoa J (1990) Chicano Literary Space: Cultural Criticism/Cultural Production. In Bruce-Novoa, RetroSpace: Collected Essays on Chicano Literature, Theory, and History, 157-176. Houston, Tex.: Arte Público Press.

Casanova P (1999) The world republic of letters, transl. by Malcolm DeBevoise. Cambridge, Mass. and London, UK Harvard University Press. (French original: 1999).

CEEOL (2019) Karadeniz-Blacksea-Черное море. Retrieved from https://www.ceeol. com/search/journal-detail?id=171. [Accessed 17 July 2019].

Charriere E (2018) Connected Shores, Hidden Hinterlands: Keraban the Inflexible and the Black Sea as Interliterary Community (abstract). The Black Sea Littoral, 16.

CODFREURCOR (2018) Black Sea Littoral as Literary Space. Retrieved from https:// codfreurcor.iliauni.edu.ge/wp-content/uploads/2018/04/Appel-communic ations-inEN.pdf. [Accessed 14 July 2019].

Conterio, J (2014) CfP: The Black Sea in the Socialist World. Humanities and Social Sciences Online: H-Russia. October 17, 2014. Retrieved from https://networks.h-net. org/node/10000/discussions/49082/cfp-black-sea-socialist-world. [Accessed 16 July 2019].

Çolak Y (2006) Ottomanism vs. Kemalism: Collective Memory and Cultural Pluralism in 1990s Turkey. Middle Eastern Studies 42(4): 587-602.

Domínguez C (2012) Dionýz Durišin and a Systemic Theory of World Literature. In T D'haen, D Damrosch, D Kadir (eds) The Routledge Companion to World Literature, 99-107. London: Routledge.

Domínguez C, Saussy H and Villanueva D (2015) Introducing Comparative Literature: New Trends and Applications. London \& New York: Routledge.

Duranli M, Emeç G (2018) The Humor and the Common Anecdote Types and Characters in the Countries of Black Sea Littoral (abstract). The Black Sea Littoral, 21. 
Durišin D (1989) Theory of Interliterary Process; transl. Kocmanová J and Pistek Z. Bratislava: Slovak Academy of Sciences.

Gobard Henri (1976) L'Aliénation linguistique : Analyse tétraglossique. Paris: Flammarion.

Guldager Bilde P, Hjarl Petersen, J (2008) Preface. In P Guldager Bilde, J Hjarl Petersen (eds) Meetings of Cultures in the Black Sea Region: Between Conflict and Coexistenc, 9-12e. Aarhus: Aarhus UP.

Hartog F (1980) Le Mirroir d'Herodote. Essai sur la Representation de l'autre. Paris: Gallimard.

Hibbitt R (2017) Introduction: Other Capitals of the Nineteenth Century. In R Hibbitt (ed) Other Capitals of the Nineteenth Century: An Alternative Mapping of Literary and Cultural Space, 1-30. New York: Palgrave Macmillan.

Hones S (2008) Text as it happens: literary geography. Geography Compass 2(5): 13011317.

Hones S (2010) Teaching and learning guide for: 'text as it happens - literary geography'. Geography Compass 4(1): 61-66.

Hones S (2011) Literary geography: setting and narrative space. Social \& Cultural Geography 12(7): 685-699.

Hones S (2014) Literary Geographies: Narrative Space in "Let the Great World Spin'. New York: Palgrave Macmillan.

Ilia State University (2018) The Black Sea as a Literary and Cultural Space. Retrieved from https://bit.ly/2noMZWo. [Accessed 14 July 2019].

Jacobsen M (1982) Looking for Literary Space: The Willing Suspension of Disbelief ReVisited". Research in the Teaching of English 16(1): 21-38.

Johadze G (2018) The Black Sea and the Georgian Medieval Historical Tradition (abstract). The Black Sea Littoral 30-31.

Karadeniz (2009-2018) Karadeniz-Blacksea-Черное море. Ankara: Kültür Ajans Tanıtım ve Organizasyon, nos. 1-38. Retrieved from https://www.ceeol.com/search/journaldetail?id=171. [Accessed 15 July 2019].

Karatay O (2009) 'Kara Deniz' ismi: Hazar ve Bulgar boyutundan bir bakış. [The name of Black Sea: a view from the Khazars' and Bulgars' side]. Karadeniz-Blacksea-Черное море 1(2): 53-73. Retrieved from https://www.ceeol.com/search/viewpdf?id=1936 15. [Accessed 17 July 2019].

KAREN (2014-2019) Karadeniz Araştırmalarn Enstitüsü Dergisi / The Journal of Institute of Black Sea Studies. Trabzon: Black Sea Technical University, nos. 1-7. Retrieved from http://www.ktu.edu.tr/karenjournal-archieve. [Accessed 15 July 2019].

Kaser K, Gutmeyr D (2018) "Introduction: Europe and the Black Sea Region: A History of Early Knowledge Exchange (1750-1850)". In D Gutmeyr, K Kaser, (eds) Europe and the Black Sea Region. A History of Early Knowledge Exchange (1750-1850), 930. Zurich: LIT.

Kilpatrick H (2000) Eastern Mediterranean Literatures: Perspectives for Comparative Study. In V Klemm, B Gruendler (eds) Understanding Near Eastern Literatures: A Spectrum of Interdisciplinary Approaches, 83-94. Wiesbaden: Reichert.

King C (2004) The Black Sea: A History. New York: Oxford UP.

Layton S (1995) Russian Literature and Empire: Conquest of the Caucasus from Pushkin to Tolstoy. Cambridge, UK: Cambridge UP.

Lewis MW, Wigen K (1997) The Myth of Continents: A Critique of Metageography. University of California Press, Berkeley.

Leypoldt G (2015) Shifting Meridians: US authorship in world literary space. American Literary History 27(4): 768-787. 
Licheli V, Guinashvili H (2018) Iranian Cultural Interference in Ancient Western Georgia in the Light of Archaeological and Linguistic Data (abstract). The Black Sea Littoral, 41.

Ljuckanov J (2014) "Towards Paired Histories of Small Literatures, To Make Them Communicate". Studi Slavistici 11: 285-300.

Lomidze G [Lyutskanov Y?] (2018) Comparative Literature(s) of the Black Sea Region: Conditions of Possibility (abstract). The Black Sea Littoral, 42.

Lyutskanov Y (2011) A symposium as a plot with political subtext (An envious and ethnocentric account from Sofia). LiterNet 10(143), October 2011. Retrieved from https://bit.ly/2oPL39N. [Accessed 17 July 2019].

Mamatsashvili A (2018) The Black Sea: Space of Life and Death in Georgian Fiction of the Soviet Era (abstract). The Black Sea Littoral, 46.

Manoli P (2010) Where is Black Sea regionalism heading?. Journal of Southeast European and Black Sea Studies 10(3): 323-339.

Margaryan G (2018) Les témoignages des sources arabes de 9e - 14e siècles sur la mer Noire (abstract). The Black Sea Littoral 41.

Munk Højte J (2008) "The Cities that Never Were: Failed Attempts at Colonization in the Black Sea”. In P Guldager Bilde, J Hjarl Petersen (eds) Meetings of Cultures in the Black Sea Region: Between Conflict and Coexistence, 149-162. Aarhus UP, Aarhus.

Nieling J, Rehm E (2010) Achaemenid Impact in the Black Sea: Communication of Powers. Aarhus: Aarhus UP.

Nuselovici A, Dokhturishvili M (2018) Black Sea Littoral as Literary Space: International Conference [Call for Papers]. Retrieved from https://codfreurcor. iliauni.edu.ge/wpcontent/uploads/2018/04/Appel-communications-in-EN.pdf. [Accessed 17 July 2019].

Özveren YE (1997) A Framework for the Study of the Black Sea World, 1789-1915. Review (Fernand Braudel Center) 20(1): 77-113.

Özveren, YE (2018) "Black Sea: A Sea of Literary and Cultural Distinction" (abstract). Black Sea Littoral, 5.

Parastatov S, Kondrasheva A (2018) Academic Studies of the Black Sea Region and the Northwest Caucasus (second half of the $18^{\text {th }}$ to the early $19^{\text {th }}$ century). In D Gutmeyr, K Kaser (eds) Europe and the Black Sea Region. A History of Early Knowledge Exchange (1750-1850), 313-335. Zurich: LIT.

Perenič U (2014) An overview of literary mapping projects on cities- literary spaces, literary maps and sociological (re)conceptualisations of space. Neohelicon 41(1): 1325.

Sabatos C (2018) "Picaresque Rogues in the Black Sea Interliterary Community" (abstract). The Black Sea Littoral 53.

Schmitt R (1989) "Black Sea" Encyclopaedia Iranica online. Encyclopaedia Iranica IV(3): 310-313. Available at: http://www.iranicaonline.org/articles/black-sea.

Sideri E, Roupakia LE (2017) Introduction. In Sideri, Roupakia (eds) Religions and Migrations in the Black Sea Region, 1-30. S.1.: Palgrave Macmillan.

Skvirskaya V (2018) Black Sea Mobility and (im)migrant Literature: (post-)Soviet Perspectives" (abstract). The Black Sea Littoral, 54.

SEEBSS (No year). Aims and Scope. Southeast European and Black Sea Studies Retrieved from https://www.tandfonline.com/action/journalInformation?show=aims Scope\&journalCode=fbss20. [Accessed 1 July 19].

Strauss J (2003) Who Read What in the Ottoman Empire (19th-20th centuries)?. Arabic Middle Eastern Literatures 6(1): 39-76.

Svanidze N (2018) Soviet Domination and Cultural Trauma in the Literature of the Black Sea Space Countries (abstract). The Black Sea Littoral 54-55. 
Thrift N (2006) Space. Theory, Culture and Society 23(2-3): 139-146.

Vinogradov JA (2008) "Rhythms of Eurasia nd the Main Historical Stages of the Kimmerian Bosporus in Pre-Roman Times". In P Guldager Bilde, J Hjarl Petersen (eds) Meetings of Cultures in the Black Sea Region: Between Conflict and Coexistence, 13-27 Aarhus: Aarhus UP.

Westphal B (2011) Geocriticism: Real and Fictional Spaces; transl. by Robert Tally Jr. Palgrave Macmillan, New York. (French original: 2007)

Winnicott DW (1971) Playing and Reality. NewYork: Basic Books.

Wooten CW (2000) Handbook of Literary Rhetoric. A Foundation for Literary Study by Heinrich Lausberg" (review). Classical World 93(5): 552-554. 
